\title{
Hubungan Antara Status Sosial Ekonomi dan Pengetahuan Ibu dengan Kejadian Gizi Kurang pada Balita
}

\author{
Feva Tridiyawati ${ }^{1}$, Anisa Ayu Riska Handoko ${ }^{2}$ \\ ${ }^{1,2}$ Program Studi D III Kebidanan Sekolah Tinggi IImu Kesehatan Abdi Nusantara Jakarta \\ Email: feva_tridiyawati@yahoo.com
}

\begin{abstract}
Abstrak
Tujuan penelitian ini adalah untuk mengetahui hubungan antara Status sosial ekonomi dan pengetahuan ibu dengan kejadian gizi kurang pada balita di Wilayah Kerja Puskesmas Kelurahan Jatibening tahun 2018. Sampel dalam penelitian ini adalah seluruh balita yang mengalami gizi kurang di Wilayah Kerja puskesmas Kelurahan Jatibening yang sejumlah 35 orang. Jadi metode yang digunakan dalam pengambilan sampel adalah total sampling. Dari variabel yang diteliti 19 reponden yang memiliki pendapatan keluarga $<$ UMR (<Rp.3.900.000,-) semuanya didapatkan pada status gizi kurang marasmus yaitu 19 (100\%) responden. Sedangkan 20 reponden yang mempunyai pengetahuan kurang didapatkan terbanyak pada status gizi kurang marasmus yaitu $18(90,0 \%)$ responden. Kader/pengurus cakupan Wilayah Kerja Puskesmas Kelurahan Jatibening supaya memperhatikan status gizi pada balita dikarenakan masih banyaknya status gizikurang pada balita, memberikan konseling pada ibu-ibu tentang gizi pada balita dan memberikan makanan tambahan pada balita yang memiliki status gizi kurang.
\end{abstract}

Kata kunci : Gizi kurang, balita, Status sosial, Pengetahuan

\begin{abstract}
The objective of this research is to determine the relationship between socioeconomic status and knowledge of mothers with the incidence of malnutrition in children under five in the Working Area of Jatibening Urban Health Center in 2018. The sample in this study were all children under five who experienced malnutrition in the Jatibening Urban Health Center's Work Area, which amounted to 35 people. So the method used in sampling is total sampling. The variables issued by 19 respondents who had family income $<U M R(<R p .3,900,000$, -) all were obtained in marasmus malnutrition status, namely $19(100 \%)$ respondents. While 20 respondents who had the least knowledge were received the most in the poor nutritional status of marasmus, namely 18 (90.0\%) respondents. Conclusions and Suggestions: Cadre / administrators of Work Area coverage of Sub-District Health Centers Not to mention gizipadabalitadik status because there are still many gizikurangpadabalita statuses, giving counseling to mothers about nutrition in children under five and providing additional food for toddlers who have poor nutritional status.
\end{abstract}

Keywords : Malnutrition, Toddlers, Socioeconomic status, Knowledge 


\section{Pendahuluan}

Dampak kekurangan gizi sangat kompleks, anak dapat mengalami gangguan pada perkembangan mental, sosial, kognitif dan pertumbuhan yaitu berupa ketidakmatangan fungsi organ, dimana manifestasinya dapat berupa kekebalan tubuh yang rendah yang menyebabkan kerentanan terhadap penyakit penyakit seperti infeksi saluran pernafasan, diare, demam. Permasalahan Gizi kurang dan gizi buruk merupakan permasalah yang multikompleks. Dalam usaha pemutusan rantai kekurangan gizi ini tentunya di butuhkan pemetaan yang tepat untuk dapat mengetahui permasalahan utama yang menyebabkan terjadinya gizi kurang dan gizi buruk. ${ }^{1}$

Menurut Pemantauan Status Gizi (PSG) hasil Riskesdas memperkirakan bahwa Prevalensi gizi buruk dan gizi kurang pada Balita, terdapat 3,1\% Balita dengan gizi buruk dan $11,8 \%$ gizi kurang. Masalah gizi buruk-kurang pada Balita di Indonesia merupakan masalah kesehatan masyarakat yang masuk dalam kategori sedang (Indikator WHO diketahui masalah gizi buruk-kurang sebesar 14,9\%). ${ }^{2}$

Indonesia mempunyai masalah gizi yang besar di tandai dengan masih tingginyaPrevalensi Balita pendek cenderung tinggi, dimana terdapat $8,5 \%$ Balita sangat pendek dan 19,0\% Balita pendek. Masalah Balita pendek di Indonesia merupakan masalah kesehatan masyarakat masuk dalam kategori masalah kronis (berdasarkan WHO masalah Balita pendek sebesar 27,5\%). Prevalensi Balita kurus cukup tinggi dimana terdapat $3,1 \%$ balita yang sangat kurus dan $8,0 \%$ Balita yang kurus. Masalah Balita kurus di Indonesia merupakan masalah kesehatan masyarakat yang masuk dalam kategori akut (berdasarkan WHO diketahui masalah Balita kurus sebesar $11,1 \%{ }^{2}$

Status gizi adalah status kesehatan yang dihasilkan oleh keseimbangan antara kebutuhan dan masukan nutrien dan untuk pertumbuhan dan perkembangan, balita memerlukan enam zat gizi utama, yaitu karbohidrat, protein, lemak, vitamin, mineral, dan air. Zat gizi tersebut dapat di peroleh dari makanan yang di konsumsi sehari-hari. Kebutuhan gizi seseorang adalah jumlah yang di perkirakan cukup untuk memelihara kesehatan pada umumnya. Antara asupan zat gizi dan pengeluarannya harus ada keseimbangan sehingga di peroleh status gizi yang baik. ${ }^{3}$

Balita di Jawa Barat menurut Depkes pada tahun 2016 cukup memprihatinkan. Kenaikan angka balita dengan berat badan kurang ini dirasakan karena kemampuan daya beli masyarakat golongan ekonomi bawah semakin menurun,sehingga pola pikir yang mereka anut bahwa sudah makan juga sudah bagus tanpa harus bergizi. Disisi lain muncul juga permasalahan akibat pengetahuan dan pendidikan yang harus bergizi. Disisi lain muncul juga permasalahan akibat pengetahuan dan pendidikan yang kurang akan pentignya gizi hingga ada beberapa kelompok masyarakat terutama di daerah dengan masyarakat menengah kebawah yang sebenarnya mempunyai daya beli bahan pangan yang baik namun mereka lebih mendahulukan kebutuhan tersier daripada kebutuhan primer yaitu penyedian makanan dengan gizi yang baik. ${ }^{1}$

Di wilayah Puskesmas Kelurahan Jatibening masih terdapat gizi kurang.Hasil Pemantauan status gizi balita tahun 2015 prevelansi status gizi kurang sebesar $288(14,6 \%)$, tahun 2016 status gizi kurang sebesar $166(7,67 \%)$ dan tahun 2017 status gizi kurang 324 (16, 66\%). ${ }^{1}$ Maka penulis tertarik untuk mengambil penelitian tentang hubungan antara status sosial ekonomi dan pengetahuan ibu terhadap kejadian gizi kurang pada balita di Puskesmas kelurahan Jatibening tahun 2018.

\section{Metode Penelitian}

Metode penelitian menggunakan deskriptif analitik dengan pendekatan cross sectional. Pengambilan data dilakukan dengan data primer. Instrumen pengambilan data yang digunakanadalah 
menyebarkan kuesioner dengan jumlah sampel sebanyak 35 responden (total sampling).

Penelitian ini dilaksanakan di Wilayah Kerja puskesmas Kelurahan Jatibening tahun 2018 Waktu penelitian dilaksanakan pada bulan Mei 2018 dengan jumlah sampel sebanyak 35 responden.

\section{Hasil}

Tabel 1. Analisis Univariat

\begin{tabular}{llcl}
\hline \multicolumn{1}{c}{ Variabel } & \multicolumn{1}{c}{ Kategori } & n & \% \\
\hline Gizi Kurang & Marasmus & 21 & 60 \\
& Kwashiorkor & 14 & 40 \\
Status Sosial & <UMR & 19 & 54,3 \\
Ekonomi & $(<$ Rp3.900000,-) & & \\
& $\geq$ UMR & 16 & 45,7 \\
& ( $\geq$ Rp 3.900.000,-) & & \\
Pengetahuan & Baik & 4 & 11,4 \\
& Cukup & 11 & 31,4 \\
& Kurang & 20 & 57,2 \\
\hline
\end{tabular}

Berdasarkan tabel 1 diketahui bahwa jumlah responden adalah 35 ibu yang memiliki balita. Responden yang mempunyai balita gizi kurang marasmus adalah sebanyak 21 orang $(60,0 \%)$, balita gizi kurang kwashiorkor adalah 14 orang (40,0\%). Dari 35 ibu yang memiliki balita lebih banyak yang penghasilannya dibawah UMR (<3.900.000,-) dibandingkan yang diatas UMR. Sedangkan dari faktor pengetahuan ibu balita tentang gizi kurang khususnya marasmus dan kwashiorkor sebagian besar masih dalam kategori kurang.

Dari hasil analisis bivariat berdasarkan tabel 2 dapat diketahui bahwa dari 19 reponden yang memiliki pendapatan keluarga <UMR (<Rp.3.900.000,-) semuanya didapatkan pada status gizi kurang marasmus yaitu 19 (100\%) responden, sementara itu pada 16 reponden yang memiliki pendapatan keluarga >UMR (>Rp.3.900.000,-) semuanya didapatkan pada status gizi kurang kwashiorkor yaitu 16 (100\%) responden. Hasil cross tabulasi variabel Status sosial ekonomi dengan Gizi kurang tentang kejadian Gizi kurang pada balita menunjukan hasil uji statistic chi-square diperoleh nilai p. 0,000 (p.value $<0,050$ ) yang berarti Ho ditolak dan Ha diterima artinya ada hubungan pendapatan kurang dengan gizi kurang pada balita.

Berdasarkan tabel 2 dapat diketahui bahwa dari 4 responden yang mempunyai pengetahuan baik didapatkan terbanyak pada status gizi kwashiorkor yaitu 3 $(75,0 \%)$ responden, sementara itu pada 11 responden yang mempunyai pengetahuan cukup didapatkan terbanyak pada status gizi kurang kwashiorkor yaitu $9(81,8 \%)$ responden, dan pada 20 reponden yang mempunyai pengetahuan kurang didapatkan terbanyak pada status gizi kurang marasmus yaitu $18 \quad(90,0 \%)$ responden. Hasil cross tabulasi variabel Pengetahuan Ibu dengan Gizi kurang tentang kejadian Gizi kurang pada balita menunjukan hasil uji statistic chisquarediperoleh nilai p. 0,005(p.value< 0,050 ) yang berarti Ho ditolak dan $\mathrm{Ha}$ diterima artinya ada hubungan pengetahuan ibu dengan gizi kurang pada balita.

Tabel 2. Analisis Bivariat

\begin{tabular}{llccccc}
\hline \multirow{2}{*}{ Variabel } & \multirow{2}{*}{ Kategori } & \multicolumn{4}{c}{ Gizi Kurang } \\
\cline { 3 - 5 } & & \multicolumn{2}{c}{ Marasmus } & \multicolumn{2}{c}{ Kwashiorkor } & \multirow{2}{*}{ Pvalue } \\
\cline { 3 - 5 } & & $\mathbf{n}$ & $\mathbf{\%}$ & $\mathbf{n}$ & $\mathbf{\%}$ \\
\hline \multirow{2}{*}{ Status Sosial Ekonomi } & <UMR (<Rp3.900000,-) & 17 & $89,5 \%$ & 2 & 10,5 & 0,001 \\
& $>$ UMR (>Rp 3.900.000,-) & 4 & $25,0 \%$ & 12 & 75,0 & \\
& Baik & 1 & $925.0 \%$ & 3 & $75.0 \%$ & \\
& Cukup & 2 & $18.2 \%$ & 9 & $81.8 \%$ & 0,005 \\
& Kurang & 18 & $90.0 \%$ & 2 & $10.0 \%$ & \\
\hline
\end{tabular}




\section{Pembahasan}

Berdasarkan hasil data diatas bahwa dari 19 reponden yang memiliki pendapatan keluarga <UMR (<Rp.3.900.000,-) semuanya didapatkan pada status gizi kurang marasmus yaitu 19 (100\%) responden, sementara itu pada 16 reponden yang memiliki pendapatan keluarga >UMR (>Rp.3.900.000,-) semuanya didapatkan pada status gizi kurang kwashiorkor yaitu 16 (100\%) responden.

Status sosial ekonomi merupakan suatu keadaan atau kedudukan yang diatur secara sosial dalam posisi tertentu dalam struktur masyarakat, pemberian posisi ini disertai pula seperangkat hak dan kewajiban yang hanya dipenuhi sipembawa statusnya, misalnya pendapatan, pekerjaan, dan pendidikan. ${ }^{5}$

Penelitian yang dilakukan oleh Mahardika mengenai hubungan antara pendapatan keluarga dengan status gizi kurang marasmus pada balita di Desa Selodoko Kecamatan Ampel Kabupaten Boyolali yang menyatakan bahwa pendapatan keluarga dengan status gizi kurang marasmus pada balita mempunyai nilai $\mathrm{p}=0,001$ sehingga ada hubungan antara pendapatan keluarga dengan status gizi kurang marasmus pada balita. ${ }^{6}$

Menurut pendapat peneliti di Wilayah Kerja Puskesmas Kelurahan Jatibening Status sosial ekonomi sangat berhubungan dengan kejadian gizi kurang pada balita dikarenakan daya beli keluarga di tentukan oleh tingkat pendapatan keluarga. Orang yang tidak berkecukupan biasanya akan membelanjakan sebagian besar pendapatan untuk makanan, rendahnya pendapatan merupakan rintangan yang menyebabkan orang-orang tidak mampu membeli pangan dalam jumlah yang dibutuhkan. Sebagai Tenaga Kesehatan hendaknya melakukan konseling dan penyuluhan tentang macammacam makanan yang bergizi dengan harga yang murah sehingga dapat terjangkau oleh ibu-ibu dengan penghasilan $<3.900 .000$.-
Berdasarkan penelitian di atas dapat diketahui bahwa dari 4 responden yang mempunyai pengetahuan baik didapatkan terbanyak pada status gizi kwashiorkor yaitu $3(75,0 \%)$ responden, sementara itu pada 11 responden yang mempunyai pengetahuan cukup didapatkan terbanyak pada status gizi kurang kwashiorkor yaitu 9 (81,8\%) responden, dan pada 20 reponden yang mempunyai pengetahuan kurang didapatkan terbanyak pada status gizi kurang marasmus yaitu $18(90,0 \%)$ responden.

Pengetahuan gizi adalah segala bentuk informasi mengenai zat-zat makanan termasuk sumber dan fungsinyayang diperlukan bagi tubuh serta penerapannya dalam kehidupan seharihari. Sehingga pengetahuan ibu tentang gizi balita merupakan segala bentuk informasi yang dimiliki oleh ibu mengenai zat makanan yang dibutuhkan bagi tubuh balita dan kemampuan ibu untuk menerapkannya dalam kehidupan seharihari. Kemiskinan dan kekurangan persediaan pangan yang bergizi merupakan faktor penting dalam masalah gizi kurang marasmus. Hal lain yang penting dari gangguan gizi adalah pengetahuan tentang gizi atau kemampuan untuk menyerap informasi tersebut dan diterapkan dalam kehidupan sehari-hari. $^{7}$

Penelitian ini sejalan dengan penelitian sebelumnya oleh Asriani tentang hubungan antara pengetahuan orang tua terhadap status gizi balita marasmus di Kelurahan Lampa Kecamatan Duampanua Kabupaten Pinrang yang dilakukan pada 74 responden menyatakan bahwa pengetahuan gizi ibu dengan status gizi kurang marasmus pada balita mempunyai nilai $p$ 0,016 sehingga ada hubungan yang bermakna antara pengetahuan gizi ibu dengan status gizi balita. ${ }^{8}$

Menurut pendapat peneliti pengetahuan ibu sangat berhubungan dengan kejadian gizi kurang pada balita di Wilayah Kerja Puskesmas Kelurahan Jatibening.Ibu yang berpengetahuan kurang dapat disebabkan karena kurang 
pengalaman dalam mengurus anak karena anak yang pertama atau karena ibu dengan jumlah anak yang terlalu banyak sehingga banyak anaknya tidak terurus dengan baik. maka di harapkan kepada tenaga kesehatan di Puskesmas Kelurahan jatibening lebih memperhatikan ibu-ibu yang berpengetahuan kurang dengan memberikan penyuluhan dan juga konseling tentang gizi balita agar gizi pada balita diwilayah kerjanya menjadi baik.

\section{Kesimpulan}

Ada hubungan antara status sosial ekonomi dan pengetahuan ibu dengan kejadian gizi kurang pada balita di Wilayah Kerja Puskesmas Kelurahan Jatibening Periode Mei 2018.

\section{Daftar Pustaka}

1. Frida T. Dampak gizi kurang pada balita. Jakarta; 2013.
2. Depkes RI. Laporan hasil riset kesehatan dasar (RISKESDAS). Badan penelitian dan pengembangan kesehatan. 2016.

3. Provetawati dan Kusmawati. Ilmu gizi untuk keperawatan dan gizikesehatan. Yogyakarta : Nuha Medika; 2013.

4. Puskesmas Jatibening. PSG 2017 Hasil Pemantauan Status Gizi. PSG Balita. Bekasi; 2017.

5. Roosalina M, Wahongan dan Franly Onibala. Hubungan Sosial Ekonomi Keluarga dengan Status Gizi pada Anak Usia Pra Sekolah 3-5 Tahun di Taman Kanak-Kanak GMIM Baithani Koha. E-journal Keperawatan (e-Kp). Vol.1, No. 1 (2013).

6. Mahardika A. Hubungan antara pendapatan keluarga dengan status gizi kurang marasmus pada balita di Desa Selodoko Kecamatan Ampel Kabupaten Boyolali. Skripsi. Fakultas Ilmu Kesehatan. Universitas muhammadiyah Surakarta; 2012.

7. Supriasa IDN. Pendidikan dan Konsultasi Gizi. Jakarta: EGC; 2014.

8. Asriani. Hubungan antarapengetahuan orang tua terhadap status gizi balita marasmus di Kelurahan Lampa Kecamatan Duampanua Kabupaten Pinrang. 